\title{
Sclopetaria with retinal folds
}

\author{
Vinod Kumar, Abhidnya Surve, Mousumi Banerjee
}

Dr Rajendra Prasad Centre for Ophthalmic Sciences, All India Institute of Medical Sciences, Delhi, Delhi, India

Correspondence to Dr Vinod Kumar; drvinod_agg@yahoo.com

Accepted 9 November 2020

\section{DESCRIPTION}

A 41-year-old man with a history of bullet injury 1 month ago was evaluated for decreased vision in the right eye. The patient's left eye was normal. Best-corrected visual acuity was 20/200 in the right eye. The dilated fundus showed the temporal area of bare sclera, surrounding pigmentation, overlying resolving vitreous haemorrhage and radial retinal folds extending towards the posterior pole (figure 1). These folds led to macular drag and narrowing of temporal vascular arcades. Vertical optical coherence tomography scan (figure 2) of the macula showed retinal folds with shallow neurosensory detachment. A diagnosis of sclopetaria with tractional retinal detachment was made. The patient was informed regarding the poor visual prognosis in the right eye in view of macular involvement, and no surgical intervention was made.

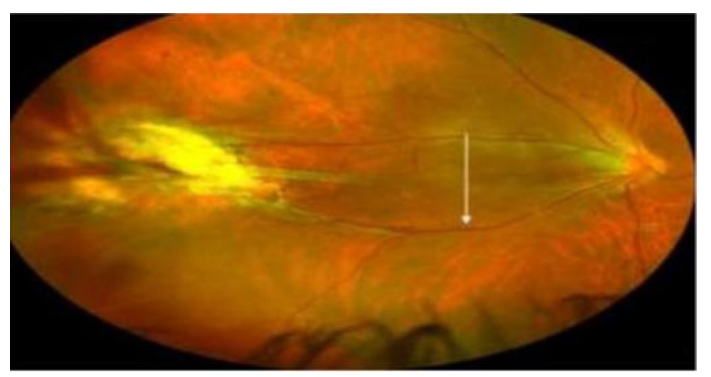

Figure 1 Ultrawide field pseudocolour image showing temporal area of bare sclera with surrounding pigmentation and retinal folds extending to the fovea (white line shows the direction of the optical coherence tomography scan).

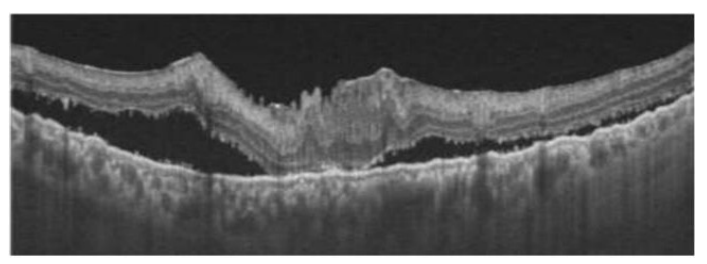

Figure 2 Vertical optical coherence tomography scan shows retinal folds with shallow neurosensory detachment.

\section{Patient's perspective}

Fundus imaging and optical coherence tomography images enabled me to better understand the cause of diminution of vision and its prognosis.

\section{Learning points}

- Sclopetaria due to significant scarring and dense adhesion can also be associated with radial retinal folds.

- The extension of the retinal folds to the macula area and associated drag can cause diminution of vision in these cases.

Sclopetaria involves rupture of the retina and choroid after non-penetrating ocular trauma with high-velocity projectile tangential to globe. The coup injury leads to stresses exceeding tensile strength of the retina and choroid, causing it to rupture but not relatively elastic posterior hyaloid or sclera. It can be associated with vitreous, intraretinal or subretinal haemorrhage. ${ }^{1}$ Inspite of the severe chorioretinal trauma, retinal detachment is rarely seen in these cases because of the firm adhesion of the retina and choroid at the area of involvement. ${ }^{2}$ The scarring at the edge of the sclopetaria is the probable cause of retinal folds in this case, which led to diminution of vision.

Contributors VK diagnosed the case. AS and MB drafted the manuscript and obtained the fundus and OCT imaging pictures. Final editing of the manuscript was done by VK.

Funding The authors have not declared a specific grant for this research from any funding agency in the public, commercial or not-for-profit sectors.

Competing interests None declared.

Patient consent for publication Obtained.

Provenance and peer review Not commissioned; externally peer reviewed.

\section{REFERENCES}

1 Goldzieher W. BeitragzurPathologie Der orbitalenSchussverletzungen. Z Augenheilkd 1901;6:277-85.

2 Ahmadabadi MN, Karkhaneh R, Roohipoor R, et al. Clinical presentation and outcome of chorioretinitis sclopetaria: a case series study. Injury 2010;41:82-5. 
Copyright 2020 BMJ Publishing Group. All rights reserved. For permission to reuse any of this content visit https://www.bmj.com/company/products-services/rights-and-licensing/permissions/

BMJ Case Report Fellows may re-use this article for personal use and teaching without any further permission.

Become a Fellow of BMJ Case Reports today and you can:

- Submit as many cases as you like

Enjoy fast sympathetic peer review and rapid publication of accepted articles

Access all the published articles

Re-use any of the published material for personal use and teaching without further permission

Customer Service

If you have any further queries about your subscription, please contact our customer services team on +44 (0) 2071111105 or via email at support@bmj.com.

Visit casereports.bmj.com for more articles like this and to become a Fellow 